\title{
Nataliia Safonova
}

Oles Honchar Dnipro National University, Ukraine

\section{Linguistic Consciousness and Foreign Language Learninig}

\begin{abstract}
The article deals with the issues where linguistic consciousness as a sociolinguistic phenomenon is successfully revealed in FLT, namely, in problematic questions of language learning. It covers the description of linguistic consciousness and some aspects of its influence on the process of development of students' communicative competence. It is emphasized that the philosophy of lifelong learning has become a widespread phenomenon in modern society. Learning a foreign language can be considered an important means of forming linguistic consciousness and the ability to conduct intercultural dialogues. The correlation of two languages and cultures (Ukrainian and foreign ones) helps to outline their national specific features, which contribute to a deeper understanding of both the foreign and the native language and culture. Any education system is open and fairly stable. As for the methods and learning tools, they can vary depending on the applicable learning concept. The article gives a detailed description of the development of linguistic consciousness of Ukrainian students from different social groups while learning English. So linguistic consciousness is a reflection of the actual language sphere contributes to the development of both communicative and multilingual competences. The main objective of the use of modern educational technologies is to increase the level of the communicative competence and linguistic consciousness in students, their educational achievements and to improve the quality of language education.
\end{abstract}

Keywords: linguistic consciousness, foreign language teaching (FLT), multilingualism, social group, communicative competence.

\section{Introduction}

Any education system is an open and fairly stable system. Therefore, its components, such as the goals and content of the teaching, must remain unchanged in any form of education within the same state, in accordance with the programs and standards of education adopted in this country. As far as methods, organizational forms and learning tools are concerned, they can vary depending on the applicable learning concept. That is why, we consider it urgent to ensure the development of linguistic consciousness of Ukrainian students from different social groups when learning English with websites. In the course of studying this problem, the aim is to analyze the theoretical material and attempt to generalize innovative methods of teaching a foreign language and educating the students' linguistic consciousness with the use of websites. The aim requires several objectives: analysis of available literature on a specific topic, identifying 
features of web resources and their impact on the educational process in general, determining the role of the Internet as a means of teaching/learning foreign languages in high school.

The need for a modern personality to adapt to the conditions of the multicultural and multilinguistic world greatly enhances interest in language education. Today, studying a foreign language can be considered an important means of forming our consciousness and the ability to conduct intercultural dialogue. As it is well known, the philosophy of a modern European in terms of lifelong learning is becoming more and more popular among Ukrainians, as it promotes awareness that the knowledge of a foreign language is not just an advantage but also a key to a successful future. The Ministry of Education and Science of Ukraine developed and approved the Concept of the implementation of the state policy in the sphere of reforming the comprehensive secondary education "New Ukrainian School", one of the basic tasks of which is the formation of the basic students' competencies. Among the ten competencies, communication in foreign languages is the key, which includes the ability to understand the language expressed properly, to express and interpret in writing and interpretation concepts, thoughts, feelings, facts and views (through hearing, speaking, reading and writing) in a wide range of social and cultural contexts (Гриневич, 2017).
In this aspect, the English language has certain advantages over other subjects from the school curriculum. Today modern youth does not exist without communication in social networks. Young people plan to acquire modern education and the profession in the future, which in turn requires mastery of the foreign language. The rapid development of information technology has been an impetus for the transformation of educational system, reflecting new demands on members of society and changing the educational paradigm. One can confidently state that there is a tendency to merge education and information technology. The wide spread of Internet technologies in society and in the educational environment predetermined the relevance of forming a new view on the content of education, finding new methods, forms and means of learning. The rapid process of the practical use of social networks in education should also be mentioned. According to the new program for secondary schools, the teaching of foreign languages implies the practical mastery of speech skills by pupils at a level sufficient for foreign language communication. The main principles of the program are communicative orientation, personal orientation, student autonomy and integrated teaching of types of speech activity. Today, are the opportunities for obtaining distant education with the help of modern information technologies are becoming more and more important. The 
global Internet network opens up access to information in the scientific centers of the world, which creates real conditions for selfeducation, expansion of the horizons, and advanced training. It is possible to organize joint projects and exchange experiences of teachers, students, scholars.

The main condition of the educational process in the institution of general secondary education is its personal orientation, aimed at ensuring that each student becomes a full, selfsufficient, creative subject of activity, knowledge and communication. Pedagogical science is looking for new models of organization of educational process, to create qualitatively new relationships between subjects of study, aimed at humanizing the educational process. One of the ways of modernizing foreign language education is the creative use of innovative educational technologies and web resources. An analysis of innovative activity in the teaching of foreign languagesshows that in practice technologies are mainly implemented, among which one can distinguish: personally oriented education and education, civic education, profile education, technology of group learning activity, the theory of level differentiation of training, information and communication technologies, project methodology, interactive technologies, technology of formation of a creative person, technology of humanization of pedagogical activity, development of critical and creative thinking, the theory of gaming technologies. The use of information and communication technology increases the intensity of learning, develops the creative abilities of students. So, the use of web resources involves modeling life situations, role-playing games, joint problem solving based on the analysis of circumstances and the situation. Educational technology of using web resources in the process of learning a child is a collection of various pedagogical techniques that encourage students to research creative activity, create conditions for their awareness of the material, generalization of the received knowledge. This technology prepares new generation children who can communicate, listen and hear others, to think. It is based on the idea of creative collaboration between teachers and students. When introducing this technology, knowledge is assimilated better, since interactive techniques are designed not to memorize, but to a thoughtful, creative process of knowing the world, to set the problem and find ways to solve it.

\section{Theoretical background}

Today, an active approach to the use of information and communication technologies in schools is not limited to electronic textbooks or manuals. Network technologies, and first of all the Internet, are now one of the means of providing equal access to quality education, an integral part of the educational sector. The Internet today is the most important socio- 
economic communication of our civilization. Network users not only "consume" information, but also constantly replenish it with various information resources. The Internet as a technical means of personal development significantly contributes to its self-realization and expands social opportunities. In the teaching a special emphasis is put on the child's own activities in the search, understanding and processing of new knowledge. The teacher acts as the organizer of the learning process. Today we can say that the Internet technologies are part of the general informational culture of teachers and students. he issue of integrating the Internet into education and, in particular, its use in teaching foreign languages, is very relevant. This is due to the fact that when using the Internet as a means of teaching a foreign language, the goals and objectives of education and education are realized.

Electronic resources are electronic data (in the form of symbols, graphic, audio, video, or combinations thereof) that can be placed on any electronic medium, and also published on a local or global network. Thus, educational electronic resources are information resources that can be presented as text, graphic, audio, video data or combinations thereof that reflect a particular subject area of education and are intended to provide a learning process for the personality, the formation of its knowledge, skills and abilities. The electronic resources must have a high level of performance, a beautiful design, a fullness of material, provide quality methodological tools and quality of technical execution, comply with didactic principle (Tsehelska, 2014).

Thus, educational web resources provide information-presentation, advisory, informational, methodological, educational, educational support for the interaction of actors, open new opportunities for interaction with the public. Using the classification, it is possible to purposefully search the necessary resource in the web space of the Internet, not spending too much time on unsustainable searches.

The main aim of teaching a foreign language is the formation of communicative competence, and all other goals (educational, educational, developing) are realized in the process of accomplishing this main aim. Communicative competence in its contemporary understanding implies the formation of the ability to intercultural interaction (Richards, 2006). Proper use of web resources can greatly facilitate the teaching/learning of students to situations of real communication. At the lesson it is almost impossible to form one language skill. For example, when working with audio texts, podcasts or video recordings, we simultaneously work out lexical, grammatical, and phonetic skills. Audiotexts provide information and background for discussion, 
which, in turn, involves further development of speaking skills (O’Malley, Chamot, 1990). In addition, a variety of engaging platforms can become a real helper in mastering key aspects of English. For example, Grammarly and Ginger are a useful resource for improving writing skills, because the above services are able to correct errors with their detailed explanations. The LearningEnglish BBS course offers interactive visualized exercises that improve listening, reading, learning new vocabulary and correct pronunciation. An engaging LyricsTraining site in game form offers to work on spelling and listening at the same time, listening to songs or watching popular video clips.

The world-famous YouTube is perhaps the most affordable video hosting service that can be used to improve listening skills. Moreover, students can be involved in the creation of their own content, thereby working out the talk. At the moment, YouTube has great potential for the use in the educational process, as video clips can enrich the lesson, diversify it, and inspire teachers to create their own video curriculum, video tutorial, or interactive video with tasks and additional comments. Among the resources with a wide choice of courses, Coursera is leading a large-scale project that publishes free English-language online courses in various fields of knowledge in the format of video collections from leading universities of the world, and the test takes place in testing mode. EdX is a library of interactive courses, founded by the Massachusetts Institute of Technology and Harvard University. Lectures on the platform are held in several languages, but English remains the main language. Significant additional opportunities arise when using information resources and the Internet services in the process of project activity of schoolchildren. Only through the Internet can you create a real linguistic environment and put the task of forming the need for learning a foreign language based on intensive communication with native speakers, working with authentic literature of the most diverse genre, listening to original texts written by native speakers.

The easiest project is e-mail correspondence. The benefits of this type of correspondence are obvious: students have a real opportunity to use foreign language as a means of communication, to master the basic skills of work on a computer, to get interesting information from them from the authentic source in the shortest possible time. The role of a foreign language teacher is to encourage students to provide them with linguistic assistance in order to use the information received in a classroom in the form of individual tasks. Very interesting interdisciplinary projects are organized around a specific problem. These can be international creative projects. In any case, a foreign language performs its primary function of 
communication. Students not only solve a certain problem, but also get acquainted with the national and cultural characteristics of partner countries. Consequently, language learning naturally takes place on a sociocultural background.

The application of information communicative technologie has not only advantagies. Bijeikienè et.al. (writes that "the application of ICT extends the learners' scope of interaction from the learner-teacher and learner-learner interaction to the computerbased interactive activities and extends the ways of communication from the face-to-face interaction to the communication via electronic means" (p. 122). At the same time, "the application of ICT to learning processes creates the learning environment which is similar to the everyday activities of the contemporary learners, as, for instance, using computers for work or entertainment” (Bijeikienè, 2011).

\section{Methods}

The aim and objectives of the article determined the choice of research methods: the method of critical analysis of literary sources, which is required for the study of theoretical material on this topic, and the method of modeling.

One of the priority directions of reforming education is the need to achieve a qualitatively new level in the study of foreign languages. Unlike other subjects, a foreign language comprises a whole branch of knowledge, since it reveals a treasury of foreign-language culture before a person. Itegration of Ukraine into the world community requires the perfect command of foreign languages through the use of educational technologies, in particular web resources. The specifics of the foreign language as a subject of study is that communication is not only the ultimate goal of learning, but also a means of achieving it. Since language remains the only universal basis of thinking, knowledge of a foreign language should be considered in terms of improving intellectual abilities (memory, imagination, critical, logical, creative thinking). Creativity is the highest manifestation of the development of the human mind. Creative ability is the ability to be surprised and to know, the ability to find solutions in non-standard situations, is the focus on discovering a new one and the ability to grasp your experience. Thanks to creative activity, the child develops the ability to independently realize their capabilities, and self-realization leads to personal growth. Implementation of this idea is impossible without the development and implementation of appropriate learning technologies and the interactive educational environment, as a way of interacting with students from different social groups. 


\section{Results and discussions}

The correlation of two languages and cultures (Ukrainian and foreign) helps to outline their national specific features, which contribute to a deeper understanding of both foreign and native language and culture. This correlation makes it possible to understand the uniqueness of these cultures, their character, which finds its embodiment in the linguistic space, and most importantly allows us to penetrate into the linguistic "picture of the world" of the two peoples. In social linguistics, the term "linguistic consciousness" is actively used, since without it it is difficult to explain the facts of linguistic behavior and find out the external causes of many linguistic changes. Linguistic consciousness as one of the forms of human consciousness is a sociopsychological category. The most comprehensive contemporary Ukrainian edition of sociolinguistics, in which the structure of the concept of "linguistic consciousness" is proposed and outlined, belongs to researcher Pylyp Seliguey. In the book "Language consciousness: structure, typology, education" the author presented the development of the typology of levels of speech consciousness, considered the principles, methods and basic content of linguistic education of Ukrainian citizens (Селігей, 2012). Consciousness is a subjective reflection of a person of the surrounding world. Thus, linguistic consciousness is a reflection of the actual language domain. Hence the definition: linguistic consciousness - it is not indifferent to the language. Such a definition clearly distinguishes the linguistic consciousness from its understanding as a linguistic picture of the world. If there is an awareness of the language of the extra-word world, then here - the awareness of the language itself (Селігей, 2012).

Philip Selighey writes: "There is neither a holistic theory, nor a single understanding of the linguistic consciousness, because different researchers invested in this concept is another meaning" (Селігей, 2009). In his article, the author suggests definitions and outlines the structure of the notion of "linguistic consciousness" "linguistic consciousness is a form of consciousness that embraces views, feelings, assessments, and guidelines on language and linguistic reality. The structure of the linguistic consciousness contains four main blocks of elements - language knowledge, feelings, assessments and guidelines "(Селігей, 2009). Such an interpretation of the linguistic consciousness coincides with the definition of Polish linguist G. Sokolovsky, who treats the MS as "views, attitudes, thoughts, representations, beliefs about the value and functioning of language in the process of communication" (Sokołowska, 2004). In the article "Place of Linguistic Consciousness in Intercultural Communication" O. Saprykin notes that "the study of the problem of the 
interaction of linguistic consciousness in intercultural communication is an important factor in the teaching of a foreign language. Kriaučiūnienè and Šiugždinienė (2010) consider the intercultural competence to be " an integral part of foreign language learning" because its development @helps to enrich the learners as intercultural personalities who are able to build and maintain intercultural relationships more effectively@ (Kriaučiūnienè, Šiugždinienè, 2010).

The interrelated study of several languages, the switching of speech codes contributes to the formation of the ability to analyze and synthesis, the linguistic and linguistic competence, as well as the elevation of the general cultural level, the expansion of the cognitive picture of the world of personality (Саприкін, 2016). The linguistic consciousness itself, according to K. Geben, is a component of communicative competence (Geben, 2003). In the opinion of L. Hnatyuk, the review of the works of modern linguists has shown that the problem of linguistic consciousness is extremely relevant and promising. Its further study in various aspects on the material of one or more languages will help to identify the deeper connection between language and consciousness, to clarify the nature of many linguistic processes and phenomena of the present and the past, and the ground-based mastery of native and foreign languages (Гнатюк, 2012).
Modern teacher is important should know the latest methods of teaching a foreign language, special techniques and techniques to optimally choose one or another method of teaching in accordance with the level of knowledge, needs and interests of students. To achieve high-quality linguistic competence communication skills, formed on the basis of language knowledge, skills and abilities, it is possible to use methods of teaching that combine communicative and cognitive goals. Innovative methods of teaching foreign languages, which are based on an innovative approach, aimed at the development and selfimprovement of the individual, to reveal its reserve capacities and creative potential. Modern communicative methods offers a widespread introduction to the learning process of active non-standard methods and forms of work for a better conscious assimilation of material (Richards, 2006). One of the technologies that provides person-oriented learning is the method of projects as a way of developing creativity, cognitive activity, and autonomy (Oxford, 1990). Projects can be classified as monoproject, collective, verbal, linguistic, written, and Internet projects. Work on a project is a multi-level approach to language learning, covering reading, listening, speaking and grammar. The project method promotes the development of active independent thinking of students and focuses them on joint research work. It is evident that 
project training is relevant to teaching children co-operation and shaping their creative abilities. An important means of innovation training is also the use of the multimedia complex in the interactive whiteboard, personal computer and multimedia projector. Such a complex combines all the advantages of modern computer technology and dedicates the process of training to a qualitatively new level. Due to its visibility and interactivity, multimedia complex allows the whole class to be actively engaged. Using the interactive whiteboard at the lesson significantly increases the efficiency of teaching students in school.

Consequently, multimedia complex provides unique opportunities for work and creativity for a great deal of ease of management. One must take into account the important psychological point: modern schoolchildren, who have computers with numerous games and programs at home, are accustomed to perceiving it as something ordinary. The possibilities of multimedia complex allow pupils to switch to the understanding that video and game programs are successfully used for learning, contribute to the development of creative activity, the capture of the subject, the creation of the best conditions for the acquisition of language skills, which ultimately ensures the effectiveness of mastering the material in foreign language lessons. The use of multimedia complex at the English lessons allows students to actively engage in the learning process, increases the motivation of learning, stimulates creative activity and promotes the development of the child's personality, expands the ability to submit educational information, it is the most efficient and time-consuming, helps students prepare for passing tests, exams, external testing. MK is a powerful tool that can be adapted for use in learning a foreign language with a wide range of topics.

Therefore, learning foreign languages will be effective precisely because of the complex application of the means of the latest innovative technologies and depends on the ability of the teacher to apply a humanistic approach to learning and from understanding the need to abandon the authoritarian teaching method. Methods of teaching foreign languages, based on the humanistic approach, help to uncover the creative potential of students and promote their development and improvement during the educational and communicative process. The process of learning a foreign language is not an automatic process of putting teaching material into the student's mind. $\mathrm{He}$ needs intense mental work of the child. This can only be achieved through active learning through innovative educational technologies. The development of communicative competence depends on the socio-cultural and sociolinguistic knowledge, skills and skills that ensure the entry of the individual into another 
society and contribute to its socialization in a new society. The main aim of foreign language education is the development of the student's personality. Therefore, it is important to teach Ukrainian students to use a foreign language as an instrument in the dialogue of cultures of the modern world, to formulate readiness for social interaction, prepare for communication in real life situations, to learn to acquire knowledge independently in order to improve in the field of the chosen future profession. It is in the lessons of a foreign language that the teacher must form students' abilities and skills in foreign language communication, to foresee achievement of such a level of communicative competence that would be sufficient for communicating in certain communicative spheres and orient students in socio-cultural aspects of the country of the language they study.

In the lessons of a foreign language, it is expedient to introduce information and communication technologies, to create a positive emotional atmosphere of spiritual enrichment, giving each child the opportunity to experience himself/herself in different forms of creativity. Exactly this, together with active forms of work, is facilitated by technologies of interactive learning, the essence of which is that the educational process takes place under the constant interaction of all students. Conduct a modern foreign language lesson with the use of design techniques, information and telecommunication technologies, computer programs in foreign languages, multimedia projects, using Internet resources, learning foreign language in a computer environment (forums, blogs, e-mail), means to create such comfortable learning conditions in which every student will feel successful, intellectual ability, learn to think critically and communicate with other people.

\section{Conclusions}

There is no doubt that learning using web resources is the most common means of learning foreign languages in the $21^{\text {st }}$ century. In this connection, there is a need to study the main aspects of the methodology of teaching a foreign language in institutions of comprehensive secondary education. The study of this problem is extremely relevant, since it represents a wide range of possibilities, which involves a critical analysis of the web resources system and independent development of exercises based on the findings. The results of this study can be practically used for a deeper study of a foreign language. Recently, the methodology of teaching foreign languages has undergone some changes regarding the organization of the learning process, teaching methods, its structure and content. Today, the most widespread and effective method of teaching and learning foreign languages is undoubtedly communicative-oriented, which is as close as possible to the real conditions of the 
foreign language environment. The main thing is to allow students to feel confident in your strength, to create natural life situations where the child can use his knowledge and talk about what interests her. The study of foreign languages in secondary schools has a practical aim - teaching students of speech activity in a foreign language. In practice, the teaching of foreign languages in high school at the present stage is increasingly felt the need to find the best means of study. In the modern method, under the influence of a number of factors, both linguistic and socio-cultural, the concept of "language teaching" is gradually replaced by a new concept - "learning language and culture", including the culture of interpersonal communication of subjects belonging to different cultures, but interesting one One from the point of view of general erudition and life experience.

The ideas of intercultural communication can be no more than trendy directions in modern methods, if not provide students with the basics of native culture, the bases of regional studies. For example, the texts on cultural monuments of London or New York should be submitted for study, along with texts on cultural monuments of Kiev, that is, to study the culture of another country with a living relationship of the culture of the native country, in which case the results of assimilation will be more productive. Mastering the values of the native land and culture by students makes their perception of another culture more precise, deep and comprehensive. Thus, as a result of the introduction of the linguistic law approach in the lessons of a foreign language, there is an update of some components of the content of training. Teacher selects relevant authentic texts for listening and reading in a foreign language lesson. These texts have a great cognitive and linguistic literary value. The teacher uses illustrated material to reveal the content of the proposed texts (leaflets, maps, slides). Such texts and their illustrations contribute to the implementation of important lessons in the teaching of a foreign language (communicative, visibility, novelty and functionality). Consequently, we can conclude that the purposeful work on the implementation of the linguistic-linguistic aspect in the lessons of a foreign language promotes, on the one hand, the increase of interest in the subject, and on the other - creates a positive motivation in the acquisition of linguistic means and acquires cultural and ethnographic information through and on the basis of these tools. This leads to the development and improvement of students linguistic liberal motivation. Purposeful and ongoing work on the implementation of the linguistic law approach in foreign language classes allows to systematize the types of exercises by means of which the teacher teaches students to acquire the necessary information from different sources. 
Thus, the use of web resources provides a sustainable result in the field of practical skills and abilities in a foreign language: on the one hand, a solid system of skills and abilities for the practical use of the foreign language as a means of interpersonal and intercultural communication is created; on the other hand, students acquire useful knowledge that they will need in the future. It should also be noted that the teaching of students of a foreign language involves mastering them with a communicative competence, which is formed on the basis of interrelated speech, socio-cultural and linguistic development of students, which requires the introduction of educational process of innovative technologies. The result of the use of modern educational technologies is to increase the level of formation of the main types of communicative competence in students, their educational achievements on the subject and the improvement of the quality of education. 


\section{REFERENCES}

Bijeikienè, V., Rašinskienè, S., Zutkienè, L. (2011). Teachers' Attitudes Towards the Use of Blended Learning in General English Classroom. KALBŲ STUDIJOS. 18 NR, 122-127.

Geben, K. (2003). Świadomość i kompetencja językowa a warstwy leksykalne w idiolektach młodzieży polskiego pochodzenia na Wileńszczyźnie. Warszawa: ELIPSA.

Kriaučiūnienè, R., Sangailaitè, V. (2016). An inquiry into the processes of lexical expansion in current English. Itteikta, metų liepos 5 d., 127-143.

Kriaučiūnienè, R., Šiugždinienè, A. (2010). Viewpoints of intercultural competence development in English language teaching/learning classroom. İteikta, m. lapkričio 15 d., 95-105.

O’Malley, J. M., Chamot, A. U. (1990). Learning Strategies in Second Language Acquisition. Cambridge University Press, 1990.

Oxford, R. L. (1990). Language Learning Strategies: What Every Teacher Should Know. Boston: Heinle\&Heinle.

Richards, J. C. (2006). Communicative Language Teaching Today. Cambridge University Press.

Sokołowska, H. (2004) Wielojęzyczność a umiejętności komunikacyjne uczniów szkół polskich na Litwie. Warszawa: Wilno: ELIPSA.

Tsehelska M. (2014). Enchancing Foreign Language Teaching in Ukraine / Збірник I конференції Українського Фулбрайтівського кола. [“Будуємо нову Україну”] (Київ, 26-27 листопада 2014 р.). Київ: Видавничий дім “Києво-Могилянська академія”, 172-178.

Гнатюк, Л. (2012). Мовна свідомість як об’єкт досліджень у західноєвропейській лінгвістиці (огляд німецькомовних праць) /Українське мовознавство, 42,73-82.

Гриневич, Л. М. (2017). Концептуальні засади реформування загальної середньої школи “Нова українська школа”. Київ: Міністрество освіти і науки України. Режим доступу: https://www.kmu.gov.ua/storage/app/media/reforms/ukrainska-shkola-compressed.pdf.

Саприкін, О. А. (2016). Місце мовної свідомості у міжкультурній комунікації. Молодий вчений. 4.1, 12-14.

Селігей, П. О. (2012). Мовна свідомість: структура, типологія, виховання. Київ: Видавничий дім “Києво-Могилянська академія”.

Селігей П. О. (2009). Структура й типологія мовної свідомості. Мовознавство, 5, 12-29.

Полат, Є. С., Бухаркін, М. Ю., Моїсеєва, М. В. (2003). Нові педагогічні та інформаційні технології в системі освіти. Москва: Видавничий центр “Академія". 